Original Research Paper

\title{
A Technical, Economic and Environmental Evaluation Study of Utilising Fixed, Single and Dual-Axis Solar Photovoltaic Systems in Boubyan and Failaka Islands in Kuwait
}

\author{
Dr. Abdulla AL-Rashidi \\ Department of Civil Engineering, The Public Authority for Applied Education and Training, Kuwait
}

\author{
Article history \\ Received: 24-08-2019 \\ Revised: 16-09-2019 \\ Accepted: 23-10-2019 \\ Corresponding Author: \\ Abdulla AL-Rashidi \\ Department of Civil \\ Engineering, The Public \\ Authority for Applied \\ Education and Training, \\ Kuwait \\ Email: aahrashidi@hotmail.com
}

\begin{abstract}
Implementing renewable energy technologies, such as solar energy, is an important step towards meeting the increasing demand for electricity in Kuwait. This would be a very helpful way of minimising the negative environmental impacts of conventional power plants. This study reports on the results of a comprehensive technical, environmental and economic evaluation of the use of a grid-connected solar photovoltaic system to generate electricity at Boubyan and Failaka islands in Kuwait. The study also evaluated the effects of using single and dual-axis tracking systems. The results showed that the obtained performance parameters are excellent and fall within the standard reference ranges of the solar photovoltaic systems. The use of tracking systems is highly beneficial and energy production increased by approximately $26 \%$ and $31 \%$ respectively as a result of implementing single and dual-axis tracking systems. The computed levelized cost of electricity (LCOE) results were $\$ 0.076 / \mathrm{kWh}, \$ 0.064 / \mathrm{kWh}$ and $\$ 0.066$ $/ \mathrm{kWh}$ respectively for fixed, single and dual-axis tracking systems. These obtained values are less than the LCOE of the conventional Kuwaiti power plants, therefore making the proposed systems economically feasible. In addition, the results revealed that single-axis tracking systems are the best option. Life cycle assessment (LCA) analysis shows that the annual energy payback time (EPBT) results obtained in this paper were $1.84,1.46$ and 1.41 years respectively. The average total $\mathrm{CO}_{2}$ emission rate was $49.58 \mathrm{CO}_{2}$, eq/kWh, $39.25 \mathrm{CO}_{2}$, $\mathrm{eq} / \mathrm{kWh}$ and $37.84 \mathrm{CO}_{2}$, eq/kWh for single and dual-axis tracking systems respectively.
\end{abstract}

Keywords: Performance Parameters, Tracking Systems, Energy Payback Time, Life Cycle Assessment

\section{Introduction}

The use of renewable energy resources as a strategic alternative to fossil fuels has increased significantly. This is due to political, economic and environmental issues such as high oil prices and environmental pollution. Renewable energy technologies play an important role in reducing the negative impacts of producing electricity by burning fossil fuels such as oil and natural gas in conventional power plants.

The state of Kuwait is keen to increase the use of clean energy resources, such as solar and wind power, to meet its growing demand for electricity. This is clearly set out in the Kuwaiti government's plan to meet $15 \%$ of its total electricity needs from renewable sources by 2030 (Al-Rashidi, 2017). The geographical location of Kuwait places it in a favourable position to utilise wind and solar resources (Al-Maamary et al., 2017; El-Katiri, 2014; Al-Rashidi, 2017).

Researchers who have investigated several potential sites for solar photovoltaic energy in Kuwait (Al-Enezi et al., 2011; Al-Rashidi, 2019, 2017; Al Otaibi and Al Jandal, 2011; Hajiah et al., 2012) have found that there is considerable potential for solar energy.

From an economic perspective, the Levelized Cost Of Electricity (LCOE) method is the most widely used tool to economically evaluate the feasibility of solar energy systems (Branker et al., 2011; Hernández-Moro and 
Martínez-Duart, 2013; IRENA, 2012; Kang and Rohatgi, 2016). This approach provides important information that will accordingly help to judge the feasibility of the proposed energy systems by comparing between them in terms of the price of produced energy per power unit. In this study, a comparison analysis was conducted between the proposed PV systems at two different sites and Kuwaiti conventional power plants in terms of electricity generation price per $\mathrm{kWh}$.

The environmental evaluation part of this study is based on published research in the renewable energy field showing that estimating the amount of greenhouse gases (GHGs) that would be avoided by implementing renewable technology systems and life-cycle assessment (LCA) are the most commonly used methods used to environmentally evaluate the solar photovoltaic systems (Alsema, et al., 2006; Alsema, et al., 2005; Fthenakis and Kim, 2011; Hong et al., 2016; Kim et al., 2014; Stoppato, 2008; Al-Rashidi, 2017 ).

The main objective of this study was to investigate a 1MW grid-connected photovoltaic system to generate electricity at two sites in Kuwait. The scope of this study includes technical, economic and environmental parameters in order to provide a clear assessment for the use of solar photovoltaic energy in Kuwait.

\section{Methods}

\section{Selected Sites and Metrological Data}

The Failaka and Bubiyan islands are the proposed sites for investigation in this study. They are $48 \mathrm{~km}^{2}$ and $683 \mathrm{~km}^{2}$ in area respectively; Fig. 1 shows their locations on the Kuwaiti solar map.

Long-term satellite meteorological data has been collected from the Kuwait Institute for Scientific Research (KISR, 2014). The main collected data are solar irradiance, temperature and wind speed.

Table 1: Design array configuration and PV module specifications (CS, 2018; SMA, 2018)

\begin{tabular}{ll}
\hline Number of modules & 4000 \\
\hline Array configuration & 200 strings \\
& 20 modules in series \\
$\mathrm{P}_{\max }$ & $250 \mathrm{~W}_{\mathrm{p}}$ \\
$\mathrm{V}_{\mathrm{mpp}}$ & $29.73 \mathrm{~V}$ \\
$\mathrm{I}_{\mathrm{mpp}}$ & $8.4 \mathrm{~A}$ \\
$\mathrm{~V}_{\mathrm{oc}}$ & $37.6 \mathrm{~V}$ \\
$\mathrm{I}_{\mathrm{sc}}$ & $8.91 \mathrm{~A}$ \\
Efficiency & $15.23 \%$ \\
Inverter model & SunnyCentral 500CP XT \\
Operating voltage & $430-850 \mathrm{~V}$ \\
\hline
\end{tabular}

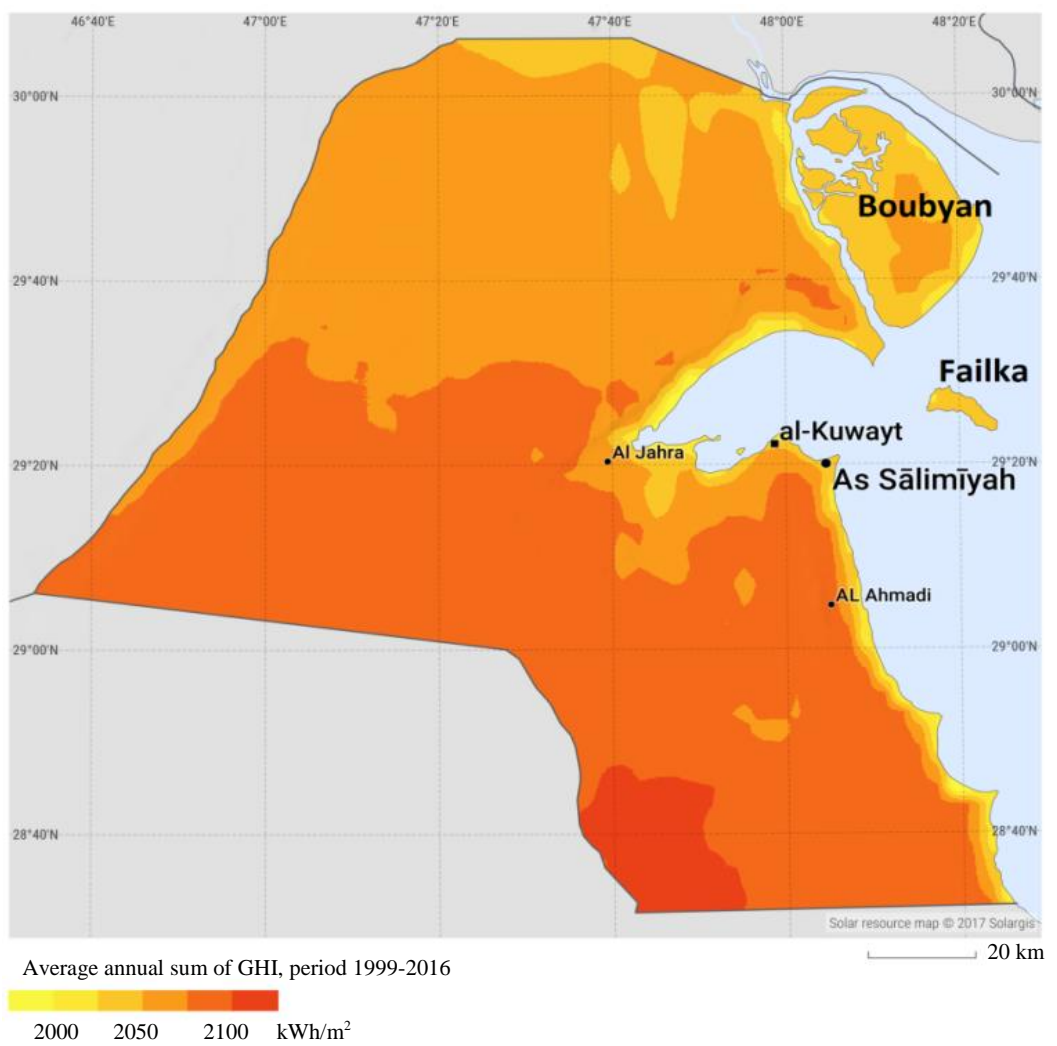

Fig. 1: Site locations on the Kuwait solar map (KISR, 2014; AL-Rashidi, 2019) 


\section{The proposed PV System}

A $1000 \mathrm{KW}$ (1MW) capacity grid connected solar photovoltaic system was investigated at the proposed sites. The selection of the type of solar modules and inverters takes into account the climate of the country, as the very hot summer temperatures will definitely affect the efficiency and performance of the proposed system. Therefore, si-poly model (S250P60 professional) PV modules and a sunny central 500CPXT inverter were selected. The types of modules and inverters selected offer a high level of performance and greater reliability in hot regions such as Kuwait (Rashed, 2014; Al-Rashidi, 2017). Table 1 lists the design array configuration of the proposed PV system.

\section{Technical Performance}

After obtaining the results from simulations using the PVsyst software of the proposed PV systems, the performance parameters (final yield (YF), reference yield $(\mathrm{YR})$, performance ratio $(\mathrm{PR})$ and capacity factor $(\mathrm{CF})$ ) of the proposed $\mathrm{PV}$ systems at the selected sites were calculated based on the International Energy Agency (IEA) criteria (Marion et al., 2005).

The following four equations were used to calculate the performance parameters:

$$
\begin{aligned}
& Y F=E_{A C} / P_{P V, \text { rated }} \\
& Y R=\left(H_{t}\right)\left(\mathrm{kWh} / \mathrm{m}^{2}\right) / G\left(1 \mathrm{~kW} / \mathrm{m}^{2}\right) \\
& P R=Y F / Y R \\
& C F=E_{A C} /\left(P_{P V, \text { rated }} x 8760\right)
\end{aligned}
$$

\section{Economic Evaluation}

In order to compare electricity generation from the conventional power plants in Kuwait and the proposed PV systems, economic evaluation analysis was conducted based on the levelized cost of electricity (LCOE) approach. The installation cost, operation maintenance costs $(\mathrm{OM})$ and capital recovery factor (CRF) are the main inputs used to calculate LCOE values. Table 2 lists the used input parameters used in the analysis. In this study, the LCOE was determined using the following equations (Smestad, 2008; Al-Rashidi, 2017):

$\mathrm{LCOE}=\frac{\text { Annual } \cos t+0 M}{\text { Annual Output }}$

Annual Cost $=($ Installation Cost $\times C R F)+0 M$

CRF is the capital recovery factor and is given in the following equation:

$\mathrm{CRF}=\frac{i \times(1+i)^{n}}{(1+i) n-1}$

Installation Cost $=$ Capital Cost $\times$ Station Capacity

Recently, a significant decrease in the installation cost from $\$ 5 / \mathrm{kW}$ has been observed; it is expected to be approximately $\$ 1 / \mathrm{kW}$ in 2020 (Nemet et al., 2017). This will definitely be a positive indication for the future implementation of solar photovoltaic systems (Nemet et al., 2017; Al-Rashidi, 2017). The installation costs for the proposed PV systems are shown in Table 3 (Chung et al., 2015; Kang and Rohatgi, 2016; NREL, 2016; AlRashidi, 2017). The OM cost was set to $3 \%$ of the investment cost per year (Ramadhan and Naseeb, 2011; Zweibel, 1999; Al-Rashidi, 2017).

Table 2: Input Parameters (Al-Rashidi, 2017)

\begin{tabular}{lll}
\hline Parameter & Value & Unit \\
\hline Capacity & 1 & MW \\
Installation Cost & & \\
Fixed tracking & 1.77 & $\$ / \mathrm{W}$ \\
Single-axis tracking & 1.91 & $\$$ \\
Dual-axis tracking & 2.05 & $\%$ \\
OM & $3 \%$ of installation cost per year & year \\
Interest Rate (i) & 5 & 25 \\
Project Life (n)
\end{tabular}

Table 3: Assumed installation rates (Al-Rashidi, 2017)

\begin{tabular}{llll}
\hline Scenario (No.) & $\begin{array}{l}\text { Fixed } \\
(\$ / \mathrm{W})\end{array}$ & $\begin{array}{l}\text { Single-axis } \\
(\$ / \mathrm{W})\end{array}$ & $\begin{array}{l}\text { Dual-axis } \\
(\$ / \mathrm{W})\end{array}$ \\
\hline 1 & 1.0 & 1.08 & 1.16 \\
2 & 1.5 & 1.62 & 1.74 \\
3 & 2.0 & 2.16 & 2.32 \\
4 & 2.5 & 2.70 & 2.90 \\
5 & 3.0 & 3.24 & 3.47 \\
\hline
\end{tabular}




\section{Sensitivity Analysis}

A sensitivity analysis was conducted to cover large numbers of changeable parameters, such as installation costs, which directly affect the obtained LCOE values. In this analysis, a range of different installation costs was assumed, varying from 1 to $3 \$ / \mathrm{kW}$ (Table 3).

For the interest rate, five scenarios, ranging from 0 to $10 \%$, were set for the analysis. The assumed lifetime values for the sensitivity analysis were from 20 and 40 years.

\section{Life Cycle Assessment (LCA)}

One of the most important environmental issues is to consider the amount of energy required to produce solar photovoltaic elements such as solar modules. This would create more accurate assessments when investigating the negative impacts of photovoltaic solar energy on the environment in terms of global warming. The LCA is the best approach that can be used in this regard, as it includes all the stages that all PV system elements pass through, from the acquisition of raw materials through to the recycling stage.

It is estimated that between 2699 and $5150 \mathrm{MJ} / \mathrm{m}^{2}$ is required for the production of multi-Si modules (Wong et al., 2016). For the analysis in this study, the data used to conduct the LCA are listed in Table 4.

Energy Payback Time (EPBT) and the $\mathrm{CO}_{2}$ emission rate were calculated using equations 9 and 10 respectively (Fthenakis et al., 2011; Basu, 2011):

$$
E P B T=\text { total energy } / \text { annual power }
$$

$\mathrm{CO}_{2}$ emission rate $\left[\mathrm{g}-\mathrm{CO}_{2}, e q / \mathrm{kWh}\right]=$

total $\mathrm{CO}_{2}$ emission during lifecycle $\left[\mathrm{g}^{\mathrm{CO}} \mathrm{O}_{2}\right] /$

annual power generation $x$ lifetime

\section{Environmental Benefits}

The environmental benefits of using PV systems are represented here in terms of the amount of greenhouse gas (GHG) emissions that would be avoided as a result of implementing the proposed PV systems instead of conventional power plants in Kuwait. This would be obtained by calculating the equivalent amount of GHG emissions resulting from conventional power plants.

\section{Results and Discussion}

The performance parameters of the proposed sites were determined on an annual basis. The detailed results of the performance parameters study are shown in Table 5. It can be seen that the average amount of energy produced was $1693 \mathrm{MWh}$ in terms of the fixed tracking systems, it was $2140 \mathrm{MWh}$ and 2225.65 MWh for the single and dual-axis tracking systems, respectively.

The average performance ratio for the fixed tracking systems, the single-axis and dual-axis tracking systems was $77.9 \%, 77.7 \%$ and $77.65 \%$ respectively. These obtained values are within the standard reference of the PV systems (Aste and Del Pero, 2010). Table 6 lists the performance ratio values for different countries.

The effect of using single and dual-axis tracking systems is significant, which can be seen in the annual produced energy, which increased by $26.4 \%$ and $31.5 \%$ for the single and dual-axis tracking systems respectively.

The average capacity factors were $19.33 \%$ for fixed tracking systems and $24.43 \%$ and $25.05 \%$ for single and dual-axis tracking systems, respectively; these obtained results are within the standard typical capacity factor reference (Hajiah et al., 2012). Table 5 clearly shows that the obtained yield factor results are excellent compared with other countries in the solar energy field (Table 7).

Table 4: Input data for LCA analysis

\begin{tabular}{lll}
\hline Energy & Value & Reference \\
\hline Single-axis tracker & $4 \mathrm{kWh} / \mathrm{kW}$ & (Perpinan et al., 2008) \\
$\begin{array}{l}\text { Dual-axis tracker } \\
\text { Total energy }\end{array}$ & $12 \mathrm{kWh} / \mathrm{kW}$ & (Al-Rashidi, 2017) \\
Fixed tracking & $1.69 \mathrm{kWh} / \mathrm{kW}$ & \\
Single-axis tracking & $2.14 \mathrm{kWh} / \mathrm{kW}$ & \\
Dual-axis tracking & $2.23 \mathrm{kWh} / \mathrm{kW}$ & \\
\hline
\end{tabular}

Table 5: Performance parameters (Al-Rashidi, 2019)

\begin{tabular}{llllcc}
\hline Site & $\begin{array}{l}\text { Annual production } \\
(\mathrm{MWh} / \text { year })\end{array}$ & $\begin{array}{l}\text { Yield factor } \\
(\mathrm{kWh} / \mathrm{kW} / \mathrm{year})\end{array}$ & $\begin{array}{l}\text { Yield } \\
\text { reference }\end{array}$ & $\begin{array}{l}\text { Performance } \\
\text { ratio }(\%)\end{array}$ & $\begin{array}{l}\text { Capacity } \\
\text { factor }(\%)\end{array}$ \\
\hline Bubiyan Island & & & & & \\
Fixed & 1713 & 1713 & 2197.9 & 77.9 & 19.55 \\
Single-axis Tracking System & 2171 & 2171 & 2794.7 & 77.7 & 24.78 \\
$\begin{array}{l}\text { Dual-axis Tracking System } \\
\text { Failaka Island }\end{array}$ & 2260 & 2260 & 2910.1 & 77.7 & 25.80 \\
$\begin{array}{l}\text { Fixed } \\
\text { Single-axis Tracking System }\end{array}$ & 1673 & 1673 & 2147.9 & 77.9 & 19.10 \\
Dual-axis Tracking System & 2109 & 2109 & 2716 & 77.7 & 24.08 \\
\hline
\end{tabular}


Table 6: Selected different performance values for multi-Si PV from literature (Al-Rashidi, 2017)

\begin{tabular}{lll}
\hline Location & Mounting type & $\begin{array}{l}\text { Performance } \\
\text { ratio }(\%)\end{array}$ \\
\hline Western Europe & Ground mounted & 75 \\
North Africa & Rooftop & 85 \\
Japan & Rooftop & 77 \\
Southern Europe & Ground mounted & 87 \\
Europe & Rooftop & 75 \\
Turkey & Ground mounted & 83 \\
Gobi desert & Rooftop & 75 \\
Southern Europe & Rooftop & 75 \\
China & LS-PV & 75 \\
\hline
\end{tabular}

Table 7: Yield factors of different countries (data taken from Hajiah et al., 2012 Al-Rashidi, 2017)

\begin{tabular}{ll}
\hline & Yield factor (YF) \\
\hline Country & $(\mathrm{kWh} / \mathrm{kW} / \mathrm{year})$ \\
Germany & $400-1300$ \\
Japan & $470-1230$ \\
Netherlands & $400-900$ \\
Italy & $450-1250$ \\
Switzerland & $450-1400$ \\
\hline
\end{tabular}

Table 8: LCOE results (Al-Rashidi, 2019)

\begin{tabular}{ll}
\hline Site & LCOE $(\$ / \mathrm{kWh})$ \\
\hline Bubiyan Island & 0.075 \\
Fixed & 0.063 \\
Single-axis Tracking System & 0.065 \\
Dual-axis Tracking System & \\
Failaka Island & 0.076 \\
Fixed & 0.065 \\
Single-axis Tracking System & 0.067 \\
Dual-axis Tracking System &
\end{tabular}

Table 9: Total $\mathrm{CO}_{2}$ emission rate and EPBT

\begin{tabular}{|c|c|c|}
\hline Site & EPBT (Year) & $\begin{array}{l}\mathrm{GHG} \\
\left(\mathrm{CO}_{2} \mathrm{~g} / \mathrm{kWh}\right)\end{array}$ \\
\hline \multicolumn{3}{|l|}{ Boubian Island } \\
\hline Fixed tracking system & 1.82 & 48.96 \\
\hline Single-axis Tracking System & 1.44 & 38.68 \\
\hline Dual-axis Tracking System & 1.39 & 37.25 \\
\hline \multicolumn{3}{|l|}{ Failaka Island } \\
\hline Fixed tracking system & 1.86 & 50.13 \\
\hline Single-axis Tracking System & 1.48 & 39.82 \\
\hline Dual-axis Tracking System & 1.43 & 38.42 \\
\hline
\end{tabular}

Table 10: The $\mathrm{CO}_{2}, \mathrm{SO}_{2}$ and $\mathrm{NO}_{\mathrm{x}}$ emissions

\begin{tabular}{llll}
\hline Site & $\mathrm{CO}_{2}$ (tons) & $\mathrm{SO}_{2}$ (tons) & $\mathrm{NO}_{\mathrm{x}}$ (tons) \\
\hline Boubian Island & & & \\
Fixed tracking system & 1028 & 1.71 & 0.26 \\
Single-axis tracking system & 1303 & 2.17 & 0.33 \\
$\begin{array}{l}\text { Dual-axis tracking system } \\
\text { Failaka Island }\end{array}$ & 1356 & 2.26 & 0.34 \\
Fixed tracking system & 1004 & 1.67 & 0.25 \\
Single-axis tracking system & 1265 & 2.11 & 0.32 \\
Dual-axis tracking system & 1315 & 2.19 & 0.33 \\
\hline
\end{tabular}

The detailed LCOEs results are listed in Table 8 . The average obtained results were $0.076 \$ / \mathrm{kWh}$ for the fixed tracking systems and 0.063 and $0.065 \$ / \mathrm{kWh}$ for the single and dual-axis tracking systems respectively. These values decreased by $15.23 \%$ and $12.58 \%$ as a result of using single and dual-axis tracking systems respectively.

In order to compare the LCOE values of the proposed PV system in this study with electricity production in Kuwaiti conventional power plants, the LCOE value for the Kuwaiti conventional power plants was set to 0.12 $\$ / \mathrm{kWh}$ (Ramadhan and Naseeb, 2011). Accordingly, it is apparent that all LCOE values are lower than 0.12 $\$ / \mathrm{kWh}$; the proposed PV systems are therefore economically feasible. In addition, Table 8 reveals that the tracking systems have obvious impacts on the obtained LCOEs as they decreased significantly as a result of implementing solar tracking systems, specifically single-axis tracking systems.

Figure 2 illustrates LCOE versus other scenarios. The computed LCOE values ranged from 0.043 and 0.128 $\$ / \mathrm{kWh}$ for the fixed tracking systems and between 0.037 and $0.11 \$ / \mathrm{kWh}, 0.038$ and $0.113 \$ / \mathrm{kWh}$ for the single and dual-axis tracking systems respectively. This means that the proposed PV systems are economically feasible for all scenarios, except scenario 5, as its calculated LCOE is more than $0.12 \$ / \mathrm{kWh}$.

The effect of installation costs on the LCOE values is directly proportional to the LCOE values (Fig. 3). Figure 4 introduces the LCOE values with different interest rates; the computed LCOE values varied between 0.044 and $0.117 \$ / \mathrm{kWh}$ for the fixed tracking systems and between 0.037 and $0.100 \$ / \mathrm{kWh}$ and 0.038 to $0.102 \$ / \mathrm{kWh}$ for the single and dual-axis tracking systems, respectively.

Figure 5 displays the obtained LCOE values for different lifetime periods. According to recently conducted research and the fact that this technology has still not reached maturity, the results obtained in this analysis are excellent.

Table 9 lists the obtained $\mathrm{CO}_{2}$ emission rates and EPBT for the proposed PV systems at Boubyan and Failaka islands. The computed average EPBT is 1.84 years for the fixed tracking system where the average EPBT for the single and dual-axis tracking system is 1.46 years and 1.41 years respectively. The average $\mathrm{CO}_{2}$ emission rates are $49.58 \mathrm{~g}-\mathrm{CO}_{2}, \mathrm{eq} / \mathrm{kWh}$ for the fixed tracking systems and $39.25 \mathrm{~g}-\mathrm{CO}_{2}, \mathrm{eq} / \mathrm{kWh}$ and $37.84 \mathrm{~g}$ $\mathrm{CO}_{2}$,eq/kWh for the single-axis and dual-axis tracking systems respectively.

The effects of GHGs on the environment were investigated. Table 10 shows the $\mathrm{CO}_{2}, \mathrm{SO}_{2}$ and $\mathrm{NOx}$ emissions that would be avoided as a result of implementing the proposed PV systems. An average amount of 1,116 tons of $\mathrm{CO}_{2}, 1.69$ tons of $\mathrm{SO}_{2}$, and 0.225 tons of NOx would be avoided by using the fixed tracking systems. 
Abdulla AL-Rashidi / American Journal of Engineering and Applied Sciences 2019, 12 (4): 495.502

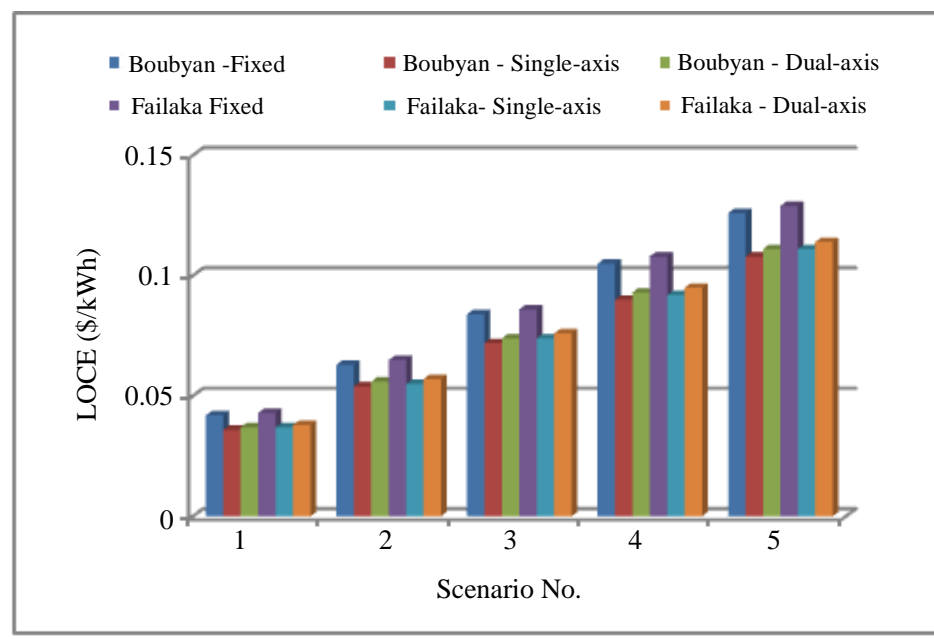

Fig. 2: LCOEs for different scenarios with different tracking systems

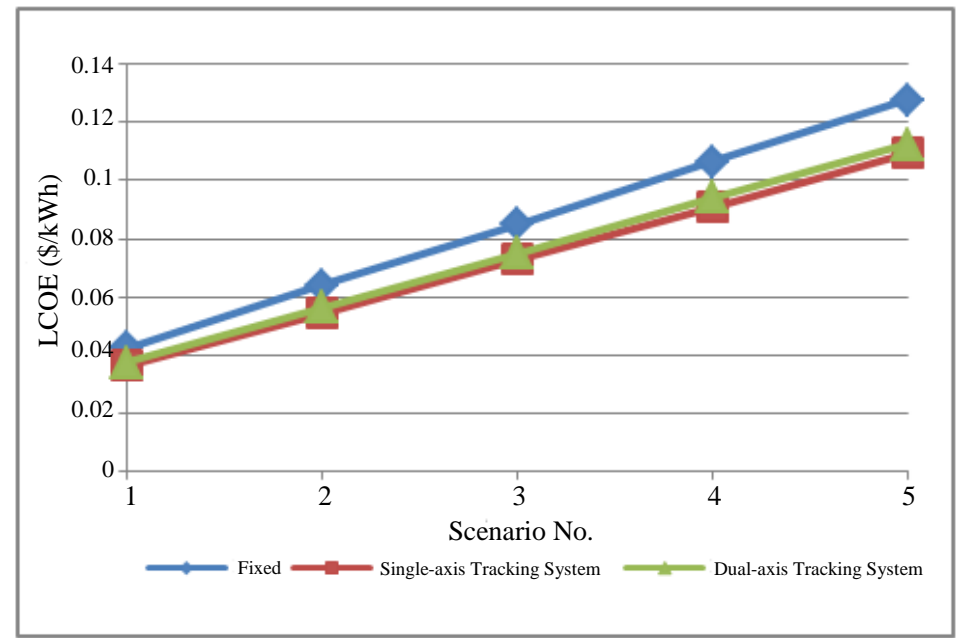

Fig. 3: Average LCOEs for different scenarios (Al-Rashidi, 2019)

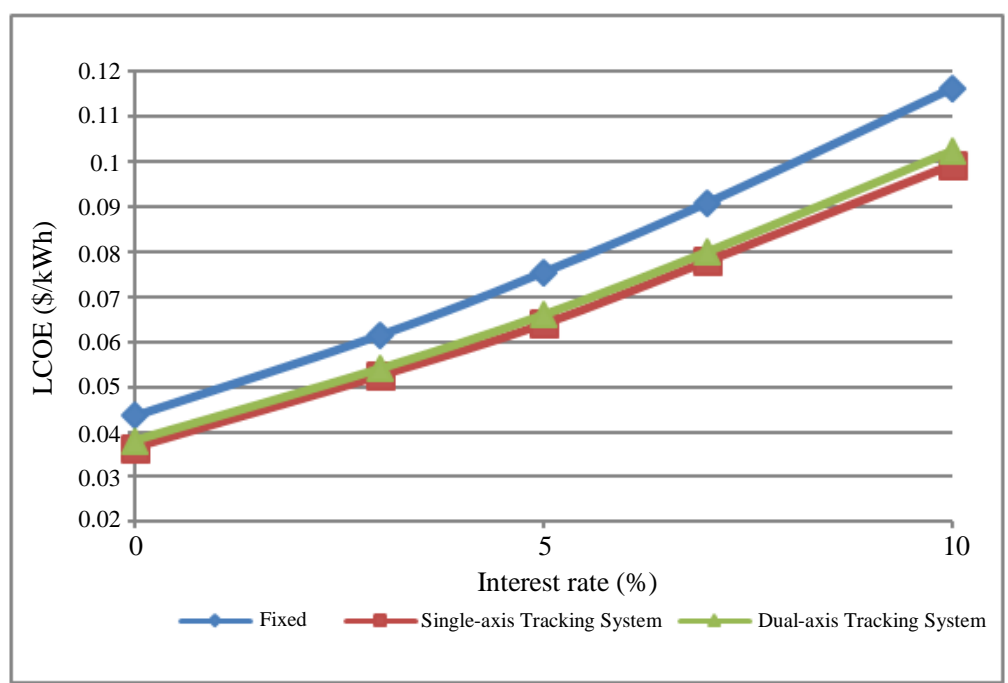

Fig. 4: Average LCOEs for different interest rates (Al-Rashidi, 2019) 


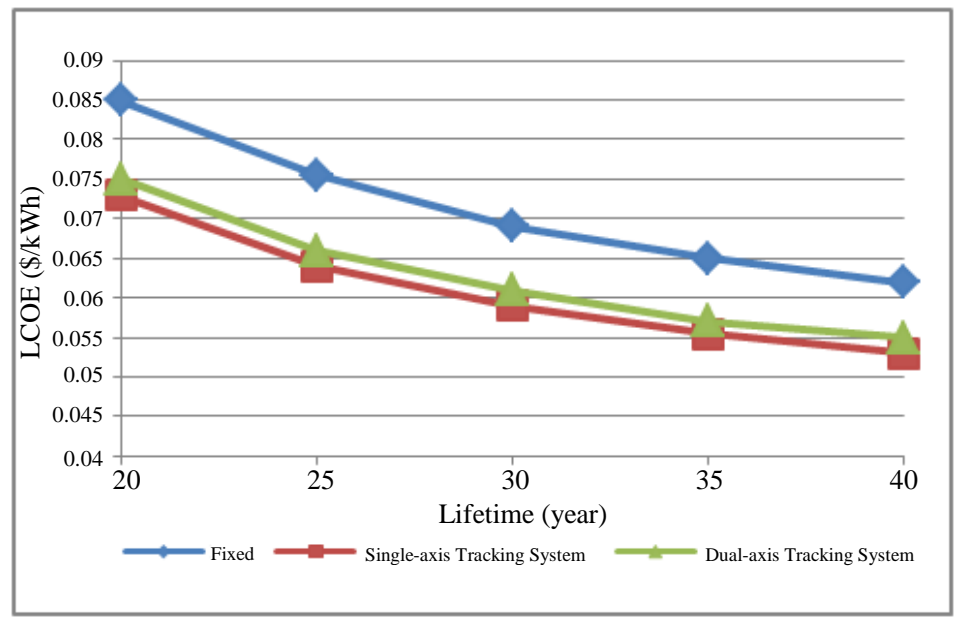

Fig. 5: Average LCOEs for different lifetime periods (Al-Rashidi, 2019)

\section{Conclusion}

The main performance parameters of a $1 \mathrm{MW}$ gridconnected PV system were investigated at Boubyan and Failaka islands in Kuwait, along with an assessment of the effect of utilising single and dual-axis solar tracking systems. The amount of electricity produced varied between 1673 and $1713 \mathrm{MWh}$ for the fixed tracking systems and from 2109 and $2171 \mathrm{MWh}$ and 2191.3 and $2260 \mathrm{MWh}$ for the single and dual-axis tracking systems respectively. The amount of energy produced increased by $26 \%$ and $31 \%$ due to the use of single and dual-axis tracking systems respectively.

The average computed LCOE values were $\$ 0.076$ $/ \mathrm{kWh}$ for the fixed solar tracking systems and $\$ 0.064$ $/ \mathrm{kWh}, \$ 0.066 / \mathrm{kWh}$ for the single and dual-axis tracking systems respectively. The results of LCOE analysis revealed that the proposed PV system is economically feasible and the single-axis tracking system is the best option. Optimistic results can be drawn from the sensitivity analysis for the future of implementation of the solar photovoltaic energy in Kuwait.

The energy payback time and the average total $\mathrm{CO}_{2}$ emission rate values computed in this research are encouraging and stand to make a positive contribution in terms of achieving environmental targets. In addition, the emission of large amounts of greenhouse gases would be avoided.

\section{References}

Al Otaibi, A. and S. Al Jandal, 2011. Solar photovoltaic power in the state of Kuwait. Proceedings of the 37th IEEE Photovoltaic Specialists Conference, Jun. 19-24, IEEE Xplore press, Seattle, WA, USA.

DOI: 10.1109/PVSC.2011.6186598.
Al-Enezi, F.Q., J.K. Sykulski and N.A. Ahmed, 2011. Visibility and potential of solar energy on horizontal surface at Kuwait area. Energy Proc., 12: 862-872. DOI: 10.1016/j.egypro.2011.10.114Get

Al-maamary, H.M.S., H.A. Kazem and M.T. Chaichan, 2017. Renewable energy and GCC States energy challenges in the 21 st century: A review. Int. J. Comput. Applied Sci., 2: 11-18.

DOI: 10.24842/1611/0018

Al-Rashidi, A., 2017. Investigating the feasibility of solar photovoltaic systems in Kuwait. Loughborough University.

Al-Rashidi, A., 2019. Feasibility Study of Utilising 1 mw Grid-Connected Solar Photovoltaic System in Boubyan and Failaka Islands. 1st Edn., Oxford, United Kingdom, ISBN: 978-1-912532-05-6.

Alsema, E. and D. Wild-Scholten, 2006. Environmental impacts of crystalline silicon photovoltaic module production. Mater. Res. Soc. Symp. Proc., 895: 1-160. DOI: 10.1557/PROC-0895-G03-05

Alsema, E.A., M.J. De Wild-Scholten and V.M. Fthenakis, 2006. Environmental impacts of PV electricity generation - a critical comparison of energy supply options. Proceedings of the 21st European Photovoltaic Solar Energy Conference, Sept. 4-8, Dresden, Germany. DOI: $10.4229 / 24$ thEUPVSEC2009

Aste, N. and C. Del Pero, 2010. Technical and economic performance analysis of large-scale ground-mounted PV plants in Italian context. Prog. Photovoltaics Res. Appl., 18: 371-384. DOI: 10.1002/pip.984

Branker, K., M.J.M. Pathak and J.M. Pearce, 2011. A review of solar photovoltaic levelized cost of electricity. Renew. Sustain. Energy Rev., 15: 4470-4482. DOI: 10.1016/j.rser.2011.07.104 
Chung, D., C. Davidson, R. Fu, K. Ardani and R. Margolis, 2015. U.S. Photovoltaic prices and cost breakdowns: Q1 2015 benchmarks for residential. Commercial and Utility-Scale Systems, National Renewable Energy Laboratory.

CS, 2018. A world of complete PV solutions. A world Complet. PV Solut.

El-katiri, L., 2014. Prospects for renewable energy in GCC states: Opportunities and the Need for Reform.

Fthenakis, V., R. Frischknecht, M. Raugei, H.C. Kim and E. Alsema et al., 2011. Methodology guidelines on life cycle assessment of photovoltaic electricity. Methodol. Guidel. Life Cycle Assess. Photovolt. Electr. IEA PVPS T, International Energy Agency Photovoltaic Power Sys.

Fthenakis, V.M. and H.C. Kim, 2011. Photovoltaics: Life-cycle analyses. Sol. Energy, 85: 1609-1628. DOI: 10.1016/j.solener.2009.10.002

Hajiah, A., T. Khatib, K. Sopian and M. Sebzali, 2012. Performance of grid-connected photovoltaic system in two sites in Kuwait. Int. J. Photoenergy. DOI: 10.1155/2012/178175

Hernández-Moro, J. and J.M. Martínez-Duart, 2013. Analytical model for solar PV and CSP electricity costs: Present LCOE values and their future evolution. Renew. Sustain. Energy Rev., 20: 119-132. DOI: 10.1016/j.rser.2012.11.082

Hong, J., W. Chen, C. Qi, L. Ye and C. Xu, 2016. Life cycle assessment of multicrystalline silicon photovoltaic cell production in China. Sol. Energy, 133: 283-293. DOI: 10.1016/j.solener.2016.04.013

IRENA, 2012. IRENA Renewable energy cost analysis series.

Kang, M.H. and A. Rohatgi, 2016. Quantitative analysis of the levelized cost of electricity of commercial scale photovoltaics systems in the US. Sol. Energy Mater. Sol. Cells, 154: 71-77.

DOI: 10.1016/j.solmat.2016.04.046

Kim, B.J.U., J. Lee yong, K. Kim hwan and T. Hur, 2014. Evaluation of the environmental performance of sc-Si and mc-Si PV systems in Korea. Sol. Energy 99: 100-114.

DOI: 10.1016/j.solener.2013.10.038

KISR, 2014. Kuwait Institute for Scientific Research.
Marion, B., J. Adelstein, K. Boyle, H. Hayden and B. Hammond et al., 2005. Performance parameters for grid-connected PV systems. Proceedings of the 31st IEEE Photovoltaic Specialists Conference, Jan. 3-7, IEEE Xplore press, FL, USA, pp: 1601-1606. DOI: $10.1109 /$ PVSC.2005.1488451

Nemet, G.F., E. O’Shaughnessy, R. Wiser, N. Darghouth and G. Barbose et al., 2017. Characteristics of lowpriced solar PV systems in the U.S. Appl. Energy, 187: 501-513. DOI: 10.1016/j.apenergy.2016.11.056

NREL, 2016. Distributed generation energy technology capital costs.

Perpinan, O., E. Lorenzo, M. Castro and R. Eyras, 2008. Energy payback time of grid connected PV systems: Comparison between tracking and fixed systems. Prog. Photovolt Res. Appl., 17: 137-147. DOI: $10.1002 /$ pip. 871

Ramadhan, M. and A. Naseeb, 2011. The cost benefit analysis of implementing photovoltaic solar system in the state of Kuwait. Renew. Energy, 36: 1272-1276. DOI: 10.1016/j.renene.2010.10.004

Rashed, A., 2014. Personal communication.

SMA, 2018. SMA solar technology.

Smestad, G.P., 2008. The basic economics of photovoltaics. Sol. Energy New Mater. Nanostructured Devices High Effic. STuC8. DOI: 10.1364/SOLAR.2008.STuC8

Stoppato, A., 2008. Life cycle assessment of photovoltaic electricity generation. Energy, 33: 224-232. DOI: 10.1016/j.energy.2007.11.012

Wong, J.H., M. Royapoor and C.W. Chan, 2016. Review of life cycle analyses and embodied energy requirements of single-crystalline and multicrystalline silicon photovoltaic systems. Renew. Sustain. Energy Rev., 58: 608-618. DOI: 10.1016/j.rser.2015.12.241

Zweibel, K., 1999. Issues in thin film PV manufacturing cost reduction. Sol. Energy Mater. Sol. Cells 59: 1-18. DOI: 10.1016/S0927-0248(99)00019-7 